\title{
Economic Disparity Analysis for Inter-Districts / Cities In South Kalimantan Province
}

\author{
Mohdari \\ STIENAS Banjarmasin, Indonesia \\ Muhammad Saleh \\ Faculty of Economics and Business, University of Lambung Mangkurat, Indonesia \\ Firda Rahmadiyanti \\ Faculty of Economic and Business, University of Lambung Mangkurat, Indonesia
}

\begin{abstract}
The study purpose is to analyze the economic development disparity and economic growth pattern and structure of inter districts / cities in South Kalimantan for 2010-2015 periods. The secondary data from years 2010-2015 were obtained from Statistics of South Kalimantan. Analysis of economic level of development disparity inter-districts / cities was conducted by Williamson index. The classification of economic growth patterns and structure is analyzed by Klassen Typology. The results showed the disparity for 2010-2015 periods tends to decrease in presence or absence of mining and excavation sectors, but the disparity within mining sector and excavation sectors have Williamson index higher at 0.513 than Williamson Index without the mining sector and excavation sectors at 0.310. The Typology Klassen analysis shows that Fast and high-growth regions are Tapin and Balangan districts, Advanced but depressed regions are Kotabaru, Tabalong and Tanah Bumbu districts, Fast growth regions are Hulu Sungai Selatan, Hulu Sungai Utara, Banjarmasin and Banjarbaru districts and relatively Underdeveloped regions are Tanah Laut, Banjar, Barito Kuala and Hulu Sungai Tengah districts.
\end{abstract}

Keywords: Economic Development, Disparity, Klassen Typology

DOI: $10.7176 / \mathrm{EJBM} / 11-10-11$

Publication date: April 30 2019

\section{INTRODUCTION}

Regional autonomy has been implemented since 2001. It makes regional governments have wider opportunities to develop regional economies. Article 1 of Law Number 23 Year 2014 explained that regional autonomy is "the authority of autonomous regions to regulate and manage interests the local community in according to its own initiative based on aspirations of community in accordance with legislation ". The regional government has the authority to make policies in accordance with community needs, potential and region difference. However, ability of each region to do the development process is different. Some regions achieve rapid development, while some other regions have slow development. This creates an imbalance in economic development between one region and others.

Measurement to assess the level of economic development disparity between regions are growth level and income per capita in. High economic growth becomes more meaningful if followed by equitable distribution of development outcomes, but in reality the development does not take place equally. 
Regional development is often focused on economic development through economic growth efforts. Economic growth relates with more production of goods and services as measured by Gross Regional Domestic Product (GRDP). The main factor to determine regional economic growth is demand for goods and services from outside, the local resources will be able to generate regional wealth because it can create employment opportunities in the area (Boediono, 1999: 1).

Development process in South Kalimantan Province has been brought many changes, including improvements in economy. One indicator to show is the changes or improvements in economic field is Gross Regional Domestic Product (GRDP) from 2010-2015 periods continues to increase (table 1). This is due to sustainable economic growth (table 2) to increase income per capita (table 3)

Table 1.

GRDP for Districts / cities in South Kalimantan Province (Million IDR)

\begin{tabular}{|l|l|l|l|l|l|l|}
\hline \multicolumn{1}{|c|}{ Districts } & \multicolumn{1}{c|}{$\mathbf{2 0 1 0}$} & \multicolumn{1}{c|}{$\mathbf{2 0 1 1}$} & \multicolumn{1}{c|}{$\mathbf{2 0 1 2}$} & \multicolumn{1}{c|}{$\mathbf{2 0 1 3}$} & \multicolumn{1}{c|}{$\mathbf{2 0 1 4}$} & \multicolumn{1}{c|}{$\mathbf{2 0 1 5}$} \\
\hline Tanah Laut & $6,939,930.3$ & $7,446,164.85$ & $7,895,319.80$ & $8,328,542.84$ & $8,582,722.87$ & $8,830,879.80$ \\
\hline Kotabaru & $11,443,591.9$ & $12,168,987.40$ & $12,963,672.06$ & $13,640,414.91$ & $14,276,190.74$ & $14,724,958.46$ \\
\hline Banjar & $7,605,086.4$ & $8,158,854.54$ & $8,670,838.49$ & $9,069,627.68$ & $9,530,588.80$ & $9,948,512.15$ \\
\hline Barito Kuala & $3,782,241.9$ & $3,942,441.73$ & $4,134,722.96$ & $4,304,969.94$ & $4,495,548.39$ & $4,728,133.78$ \\
\hline Tapin & $4,065,949.2$ & $4,332,072.51$ & $4,605,780.32$ & $4,870,635.26$ & $5,135,344.62$ & $5,343,659.97$ \\
\hline Hulu Sungai Selatan & $2,842,094.7$ & $2,995,485.14$ & $3,155,163.06$ & $3,334,465.09$ & $3,527,557.97$ & $3,741,265.84$ \\
\hline Hulu Sungai Tengah & $2,996,326.1$ & $3,175,363.70$ & $3,329,328.22$ & $3,523,288.45$ & $3,717,645.58$ & $3,944,292.79$ \\
\hline Hulu Sungai Utara & $2,039,850.7$ & $2,170,793.30$ & $2,288,014.86$ & $2,410,137.59$ & $2,554,212.97$ & $2,689,833.86$ \\
\hline Tabalong & $10,292,209.1$ & $11,036,322.63$ & $11,625,110.10$ & $12,132,178.20$ & $12,625,110.20$ & $12,937,387.89$ \\
\hline Tanah Bumbu & $10,600,137.2$ & $11,439,061.87$ & $12,158,928.02$ & $12,621,177.27$ & $13,078,247.13$ & $13,472,539.86$ \\
\hline Balangan & $6,154,980.4$ & $6,699,291.65$ & $7,147,781.65$ & $7,722,399.91$ & $8,186,802.50$ & $8,441,836.80$ \\
\hline Banjarmasin & $13,067,090.3$ & $13,740,231.39$ & $14,588,856.53$ & $15,600,542.34$ & $16,601,120.99$ & $17,562,798.74$ \\
\hline Banjarbaru & $3,475,509.9$ & $3,683,619.05$ & $3,924,616.86$ & $4,183,367.60$ & $4,460,741.46$ & $4,766,662.88$ \\
\hline
\end{tabular}

Source: BPS of South Kalimantan Province

Table. 2

GRDP Growth Rate of Districts / cities in South Kalimantan Province (Percent)

\begin{tabular}{|l|c|c|c|c|c|c|c|}
\hline \multicolumn{1}{|c|}{ Districts } & $\mathbf{2 0 1 0}$ & $\mathbf{2 0 1 1}$ & $\mathbf{2 0 1 2}$ & $\mathbf{2 0 1 3}$ & $\mathbf{2 0 1 4}$ & $\mathbf{2 0 1 5}$ & Average \\
\hline Tanah Laut & 5.98 & 7.29 & 6.03 & 5.49 & 3.05 & 2.89 & 5.12 \\
\hline Kotabaru & 6.55 & 6.34 & 6.53 & 5.22 & 4.66 & 3.14 & 5.41 \\
\hline Banjar & 4.91 & 7.28 & 6.28 & 4.60 & 5.08 & 4.39 & 4.61 \\
\hline Barito Kuala & 3.85 & 4.24 & 4.88 & 4.12 & 4.43 & 5.17 & 4.45 \\
\hline Tapin & 5.44 & 6.55 & 6.32 & 5.75 & 5.43 & 4.06 & 5.59 \\
\hline Hulu Sungai Selatan & 3.25 & 5.40 & 5.33 & 5.68 & 5.79 & 6.06 & 5.25 \\
\hline Hulu Sungai Tengah & 4.65 & 5.98 & 4.85 & 5.83 & 5.52 & 6.10 & 5.49 \\
\hline Hulu Sungai Utara & 4.32 & 6.42 & 5.40 & 5.34 & 5.98 & 5.31 & 5.46 \\
\hline Tabalong & 7.48 & 7.23 & 5.33 & 4.36 & 4.06 & 2.47 & 5.16 \\
\hline Tanah Bumbu & 6.45 & 7.91 & 6.29 & 3.80 & 3.62 & 3.01 & 5.18 \\
\hline Balangan & 5.84 & 8.84 & 6.69 & 8.04 & 6.01 & 3.12 & 6.42 \\
\hline Banjarmasin & 5.98 & 5.15 & 6.18 & 6.93 & 6.41 & 5.79 & 6.07 \\
\hline Banjarbaru & 5.80 & 5.99 & 6.54 & 6.59 & 6.63 & 6.86 & 6.40 \\
\hline South Kalimantan & $\mathbf{5 . 5 8}$ & $\mathbf{6 . 9 7}$ & $\mathbf{5 . 9 7}$ & $\mathbf{5 . 3 3}$ & $\mathbf{4 . 8 5}$ & $\mathbf{3 . 8 4}$ & $\mathbf{5 . 4 2}$ \\
\hline
\end{tabular}

Source: BPS of South Kalimantan (data processed) 
Table 3.

Per Capita GRDP of Districts / cities in South Kalimantan Province (IDR)

\begin{tabular}{|l|l|l|l|l|l|l|l|}
\hline \multicolumn{1}{|c|}{ Districts } & \multicolumn{1}{c|}{$\mathbf{2 0 1 0}$} & $\mathbf{2 0 1 1}$ & $\mathbf{2 0 1 2}$ & $\mathbf{2 0 1 3}$ & $\mathbf{2 0 1 4}$ & \multicolumn{1}{c|}{$\mathbf{2 0 1 5}$} & \multicolumn{1}{c|}{ Average } \\
\hline Tanah Laut & $23,302,901$ & $24,559,401$ & $25,591,779$ & $26,547,271$ & $26,896,824$ & $27,232,015$ & $25,688,365$ \\
\hline Kotabaru & $39,256,393$ & $40,926,858$ & $42,786,938$ & $44,182,343$ & $45,394,448$ & $45,985,604$ & $43,088,764$ \\
\hline Banjar & $14,938,559$ & $15,774,392$ & $16,447,118$ & $16,910,598$ & $17,474,589$ & $17,943,255$ & $16,576,419$ \\
\hline Barito Kuala & $13,649,867$ & $14,008,455$ & $14,477,574$ & $14,844,979$ & $15,285,313$ & $15,851,220$ & $14,686,235$ \\
\hline Tapin & $24,116,093$ & $25,292,195$ & $26,489,945$ & $27,600,671$ & $28,662,495$ & $29,396,626$ & $26,926,337$ \\
\hline Hulu Sungai Selatan & $13,336,030$ & $13,869,014$ & $14,413,916$ & $15,046,274$ & $15,714,773$ & $16,470,246$ & $14,808,375$ \\
\hline Hulu Sungai Tengah & $12,275,295$ & $12,828,612$ & $13,279,863$ & $13,878,426$ & $14,459,526$ & $15,153,338$ & $13,645,843$ \\
\hline Hulu Sungai Utara & $9,722,232$ & $10,196,209$ & $10,593,642$ & $10,994,651$ & $11,489,213$ & $11,934,343$ & $10,821,715$ \\
\hline Tabalong & $46,847,503$ & $49,336,253$ & $51,051,363$ & $52,357,513$ & $53,546,826$ & $53,997,353$ & $51,189,468$ \\
\hline Tanah Bumbu & $39,320,787$ & $40,509,748$ & $41,212,234$ & $41,220,756$ & $41,411,101$ & $41,439,305$ & $40,852,322$ \\
\hline Balangan & $54,558,174$ & $58,240,023$ & $61,046,235$ & $64,800,999$ & $67,482,174$ & $68,383,193$ & $62,418,466$ \\
\hline Banjarmasin & $20,800,087$ & $21,540,700$ & $22,534,428$ & $23,753,143$ & $24,918,264$ & $26,002,011$ & $23,258,237$ \\
\hline Banjarbaru & $17,272,017$ & $17,751,525$ & $18,338,338$ & $18,955,425$ & $19,607,654$ & $20,338,108$ & $18,710,520$ \\
\hline South Kalimantan & $\mathbf{2 3 , 4 1 8 , 4 7 3}$ & $\mathbf{2 4 , 5 6 7 , 5 2 1}$ & $\mathbf{2 5 , 5 4 7 , 7 7 3}$ & $\mathbf{2 6 , 4 2 3 , 9 0 5}$ & $\mathbf{2 7 , 2 2 3 , 3 1 2}$ & $\mathbf{2 7 , 7 9 3 , 6 0 4}$ & $\mathbf{2 5 , 8 2 9 , 0 9 8}$ \\
\hline
\end{tabular}

Source: BPS South Kalimantan (data processed)

Above data shows that value of per capita GRDP between regions have differences. It indicates the disparity of income distribution and economic growth for each districts / cities in South Kalimantan province. Regional disparity without treatment will bring adverse effects to lead to social jealousy between regions and disrupt the economy stability.

\section{LITERATURE REVIEW}

Economic development in defined as a process to increase real per capita income of a country's population in long run accompanied with an institutional system. While economic growth is interpreted as an increase in Gross Domestic Product (GDP) / Gross National Product (GNP) regardless the increase is large or smaller than the growth rate or whether economic growth occurs or not (Arsyad, 1999: 6-7). Todaro (1993: 113) showed three factors to influence economic growth, namely: capital accumulation, growth in population, labor and technological progress.

Regional economic development is a process where local governments and their communities manage the existing resources and creating a partnership pattern between local governments and private sector to create employment and stimulate the development of economic activities (economic growth) in the region (Arsyad, 1999: 108 ). Todaro (2006: 28-29) said that the development process in all societies must have at least three core objectives. First is to increase the availability and expansion the distribution of various basic necessities of life such as food, clothing, shelter, health, and security protection. Second is improvement in living standards in form of income higher, additional employment provision, improvement in education quality, and higher attention to cultural and humanitarian values. The end result to be achieved is an improvement in material welfare and fostering personal and national selfesteem. Third is expansion of economic and social choices to free them from an attitude of dependence on other people and other nations from any power that has the potential to undermine human values. 
The development success can be seen from economic growth, economic structure and smaller income disparity between residents, between regions, and between sectors. In fact, economic growth is not always followed by equitable distribution.

Disparity in economic development between regions is a phenomenon in process of regional economic development and aspects that commonly occur in economic activities of a region. One objectives of regional economic development is to reduce disparity. Increased income per capita does show the level of economic progress of a region. However, increasing per capita income does not always indicate that income distribution is more evenly. If the national income is not enjoyed equally by all levels of society, it can be said that disparity has occurred.

Theoretically, regional disparity problem was first raised by Douglas C. North in his analysis of Neo Classical Growth Theory. This theory predicts the relationship between the level of national economic development of a country and disparity between regions. This hypothesis is better known as the Neo Classical Hypothesis (Sjafrizal, 2012: 109). This hypothesis said that at beginning of a country development process, disparity between regions tends to increase. If the development process continues, gradually disparity between regions will decline. Based on this hypothesis, a temporary conclusion can be drawn that developing countries generally have higher disparity between regions, while disparity in developed countries tend lower.

Sjafrizal (2012: 119-122) mentioned five factors below to cause disparity between regions.

1. Differences in natural resources content

Very large differences in natural resources content of each region will encourage economic disparity between regions to affect production activities in the region. Regions with considerable amount of natural resources can produce certain goods and services at relatively low than areas that with few natural resources. This condition can encourage faster economic growth. The regions with little natural resource content only can produce goods and services at higher production costs and their competitiveness becomes weak which results in slow economic growth.

2. Differences in geographical conditions

These include differences in growth level and population structure, education and health levels, employment conditions, behavior and habits and work ethic. All these conditions affect the work productivity of community in the area and it can affect economic disparity between regions. Regions with good demographic conditions tend to have higher work productivity to encourage higher which will further increase the supply of employment and economic growth.

3. Slow mobility of goods and services

The mobility of goods and services includes inter-regional trade activities and migration, either government-sponsored (transmigration) or spontaneous migration. Slow mobility makes the excess production of an area cannot be sold to other areas and slow migration will cause excess labor in an area. As a result, development disparity between regions tend high, the underdeveloped regions will have difficult to encourage the development process.

4. Concentration of regional economic activities

Economic growth tends faster in an area with large concentration of economic activity. This condition will drive the regional development process through increasing employment and community income levels. The concentration of economic activities can be caused by large 
number of natural resources in certain areas, more evenly distributed transportation facilities both land, sea and air and demographic conditions

5. Allocation of inter-regional development funds

The allocation of these funds can come from government or the private sector. Fund allocation in a centralized government system is done by central government to make the development disparity between regions tends to be high. Adversely, government autonomous will allocate funds to regions to make development disparity between regions tend to be lower. Private investment is more is determined by market forces. The location advantages of an area become the strengths to attract private investment. The location advantage is determined by transportation costs of both raw materials and production output that must be spent by employers, differences in labor wages, market concentration, level of business competition and land rent. Therefore, investment tends higher urban areas than rural areas.

Fiqri Riza Jauhari (2010) examined the economic growth and disparity of inter-district income at Banjar District in South Kalimantan Province using Williamson Index analysis, Theil Entropy Index, Klassen Typology, Trend Analysis and Pearson Correlation. The results were below.

1. The 2000-2008 periods showed higher in Banjar District with average Williamson Index value of 0.379 and average theil entropy index value of 0.202 .

2. Klassen Typology for sub-districts in Banjar District can be classified into 4 groups, namely advanced and fast-growing sub-districts at Mataraman, Karang Intan, Aranio, Pengaron, Simpang Empat, Sambung Makmur, Peramasan Sub Districts, advanced but depressed districts, namely Beruntung Baru Sub district, rapidly developing subdistricts at Martapura and East Martapura Sub districts and lagging at Kertak Hanyar District, Gambut, Sungai Tabuk, Astambul, Aluh-Aluh and West Martapura Sub districts.

3. The Kuznest hypothesis on disparity level was not valid in Banjar District as evidenced by Pearson Trend and Correlation Analysis

\section{RESEARCH METHOD}

The research has quantitative descriptive type. The objects are all districts / cities in South Kalimantan Province. They are Tanah Laut, Kotabaru, Banjar, Barito Kuala, Tapin, Hulu Sungai Selatan, Hulu Sungai Tengah, Hulu Sungai Utara, Tabalong, Tanah Bumbu, Balangan, Banjarmasin City and Banjarbaru City.

This research used secondary data from Central Kalimantan Provincial Statistics Agency below.

1. GRDP of Districts / cities in South Kalimantan Province based on 2010 constant prices for 2010-2015 periods.

2. GRDP per capita of districts / cities of South Kalimantan Province based on 2010 constant prices for 2010-2015 periods.

3. GDP of South Kalimantan Province based on 2010 constant prices for 2010-2015 periods.

4. GDP per capita of South Kalimantan Province based on 2010 constant prices for 2010-2015 periods.

5. Data on Districts / cities GRDP growth rates of South Kalimantan Province in 20102015.

6. GDRP Growth rate of South Kalimantan Province for 2010-2015 periods.

7. Districts / cities population of South Kalimantan Province in 2010-2015.

The data was collected by documenting statistical published by Central Statistics Agency of South Kalimantan Province. The analysis techniques are explained below. 


\section{Disparity Levels Analysis of Inter-Districts / cities}

The development disparity between districts / cities in South Kalimantan Province was be analyzed by the Williamson Index. It uses Gross Regional Domestic Product per capita as the base data, with following formulation:

$$
V_{w}=\frac{\sqrt{\sum_{i-1}^{n}(y i-y)^{2}\left(\frac{f i}{n}\right)}}{y}
$$

Description:

$\mathrm{Vw}=$ Williamson Index for South Kalimantan Province

yi $=$ GRDP per capita of districts / cities $\mathrm{i}$

$\mathrm{y}=$ GRDP per capita for South Kalimantan Province

$\mathrm{fi}=$ total population of districts / cities $\mathrm{i}$

$\mathrm{n}=$ population of South Kalimantan Province

Williamson disparity index close to 1 will show a higher level of disparity and close to zero indicates a smaller level of disparity between districts / cities (Sjafrizal, 2012: 110).

\section{Pattern Analysis and Economic Growth Structure of Inter-Districts / Cities}

Klassen Typology was used to find the patterns and structure of economic growth among districts / cities in South Kalimantan Province. It was used to classify the patterns and structure of economic growth in each region based on two indicators, namely economic growth and regional income per capita. Based on classification typology, districts / cities development can be divided into four classifications. First, fast and high-growth regions (high growth and high income) are regions with higher economic growth level and per capita income than average of South Kalimantan Province. Second, advanced but depressed regions are regions with higher income per capita, but the economic growth level is lower than the average of South Kalimantan Province. Third, fast growth area (high growth but low income) is an area with high growth level but per capita income is lower than the average of South Kalimantan Province. Forth, relatively low area (low growth and low income) is an area with low economic growth rate and per capita income than average of South Kalimantan Province. Table 4 shows the grouping.

Table 4.

Grouping of Regional Development Based on Klassen Typology

\begin{tabular}{|c|l|l|}
\hline Growth level & Yi $>\mathrm{Y}$ & $\mathrm{Yi}<\mathrm{Y}$ \\
\hline $\mathrm{r}$ i $>\mathrm{r}$ & Fast and high-growth regions & Fast growth regions \\
\hline $\mathrm{r}$ i $<\mathrm{r}$ & Advanced but depressed regions & Underdeveloped regions \\
\hline
\end{tabular}

Source: (Sjafrizal, 1997: 30)

Description:

ri $=$ GDP growth level of district $i$

$r=$ total GRDP growth level of South Kalimantan Province 
$\mathrm{yi}=$ GDP per capita of district $\mathrm{i}$

$\mathrm{y}=$ GRDP per capita of South Kalimantan Province

\section{RESEARCH RESULTS AND DISCUSSION}

1. Economic Development Disparity Analysis of Inter-Districts / cities with Mining and Excavation Sectors

Disparity is one development problems that cannot be solved, especially in developing countries. Disparity is caused by differences in characteristics between regions to make one or several regions more advanced than others. The small disparity of GRDP per capita between districts / cities illustrates about the conditions and developments in South Kalimantan Province. It will be analyzed by the Williamson Index. Smaller Williamson index numbers or close to zero indicates that disparity is smaller, and far from zero shows the gap is widening. Williamson Index can be calculated based on population and GRDP per capita of South Kalimantan Province for 2010-2015 periods, as shown in table 5.

Table 5

\section{Williamson Index for 2010-2015}

\begin{tabular}{|c|c|c|}
\hline No & Year & Williamson Index \\
\hline 1 & 2010 & 0.518 \\
\hline 2 & 2011 & 0.521 \\
\hline 3 & 2012 & 0.520 \\
\hline 4 & 2013 & 0.518 \\
\hline 5 & 2014 & 0.513 \\
\hline 6 & 2015 & 0.488 \\
\hline \multicolumn{2}{|c|}{ Average } & 0.513 \\
\hline
\end{tabular}

Source: Research Team Calculation

Table 5 shows the average disparity of Williamson Index between districts / cities in South Kalimantan Province for 2010-2015 periods is quite high at 0.513 because it close to 1 the disparity is bigger. Williamson index disparity in 2010-2015 tends to decrease. The Williamson index in 2010 is 0.518 , increased to 0.521 in 2011 , then decrease again to 0.520 , 0.518 , and 0.513 in 2012, 2013 and 2014, respectively. The Williamson Index in 2015 decreased to 0.488 . The highest disparity was occurred in 2011 at 0.521 . This is affected by higher mining sector (coal) in GRDP of South Kalimantan Province. The mining sector did not develop evenly at districts / cities in South Kalimantan. There are seven districts with relatively large mining sectors, namely Tanah Laut, Banjar Balangan, Tabalong, Kotabaru, Tanah Bumbu, and Tapin Districts.

Lower level of disparity is caused by lower economic growth in districts / cities with large mining sector. The districts / cities with relatively small contribution from mining sector achieve faster economic growth in 2012-2015 than districts / cities with large mining sector. The greater the role of other sectors than the mining sector, such as agriculture, fisheries and forestry, manufacturing sector, construction sector and other sectors as demand from mining and excavation sectors from abroad also affects the lower disparity. The government also explores the potential in each districts / cities to make many investors enter. Figure 1 show Williamson Index disparity between districts / cities in South Kalimantan Province for 20102015 periods. 


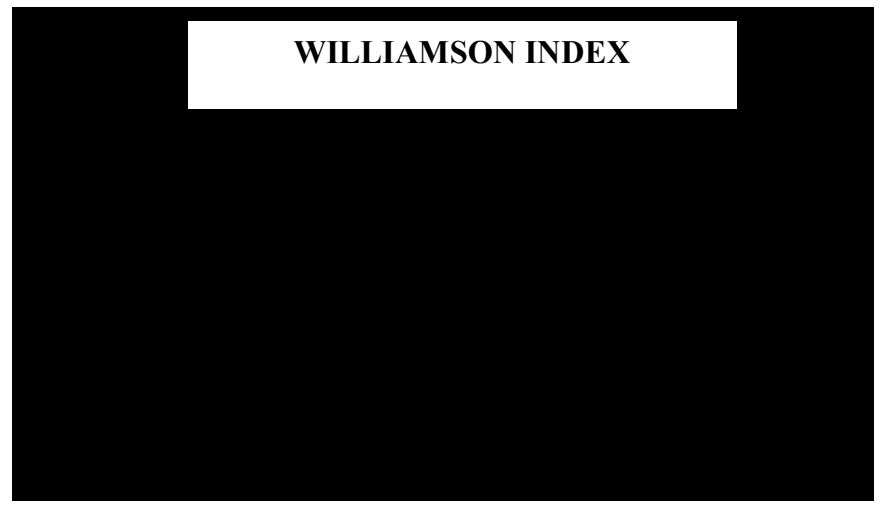

Figure 1.

Williamson Index for Mining and Excavation Sector

Source: data processed from table 5

\section{Disparity Analysis for Inter-Districts / cities Economic Development without the Mining and Excavation Sector}

This analysis compares Williamson Index with Districts / cities GRDP data in South Kalimantan Province according to business fields without mining and excavation sectors, due to large distribution of sector to South Kalimantan Province GRDP. The results show the disparity level in South Kalimantan Province is not too large, at average of 0.310 (table 6). This figure is smaller when compared with calculation of Williamson Index in mining and excavation sectors.

Table 6.

Williamson Index for 2010-2015 Period

\begin{tabular}{|c|c|c|}
\hline No & Year & Williamson Index \\
\hline 1 & 2010 & 0.317 \\
\hline 2 & 2011 & 0.313 \\
\hline 3 & 2012 & 0.311 \\
\hline 4 & 2013 & 0.311 \\
\hline 5 & 2014 & 0.308 \\
\hline 6 & 2015 & 0.303 \\
\hline \multicolumn{2}{|c|}{ Average } \\
\hline
\end{tabular}

Table 6 shows the average disparity of Williamson index without the mining and excavation sectors between districts / cities in South Kalimantan Province in 2010-2015 is relatively low level at 0.310 because Williamson index number close to 0 indicates smaller disparity. The Williamson Index disparities without the mining and excavation sectors in 2010-2015 continue to decline. Williamson Index in 2010 is 0.317 , and then the disparity figure continued to decline until finally it became 0.303 in 2015. Figure 2 shows the Williamson index disparity without the Mining and Excavation Sector between districts / cities in South Kalimantan Province in 2010-2015 periods. 


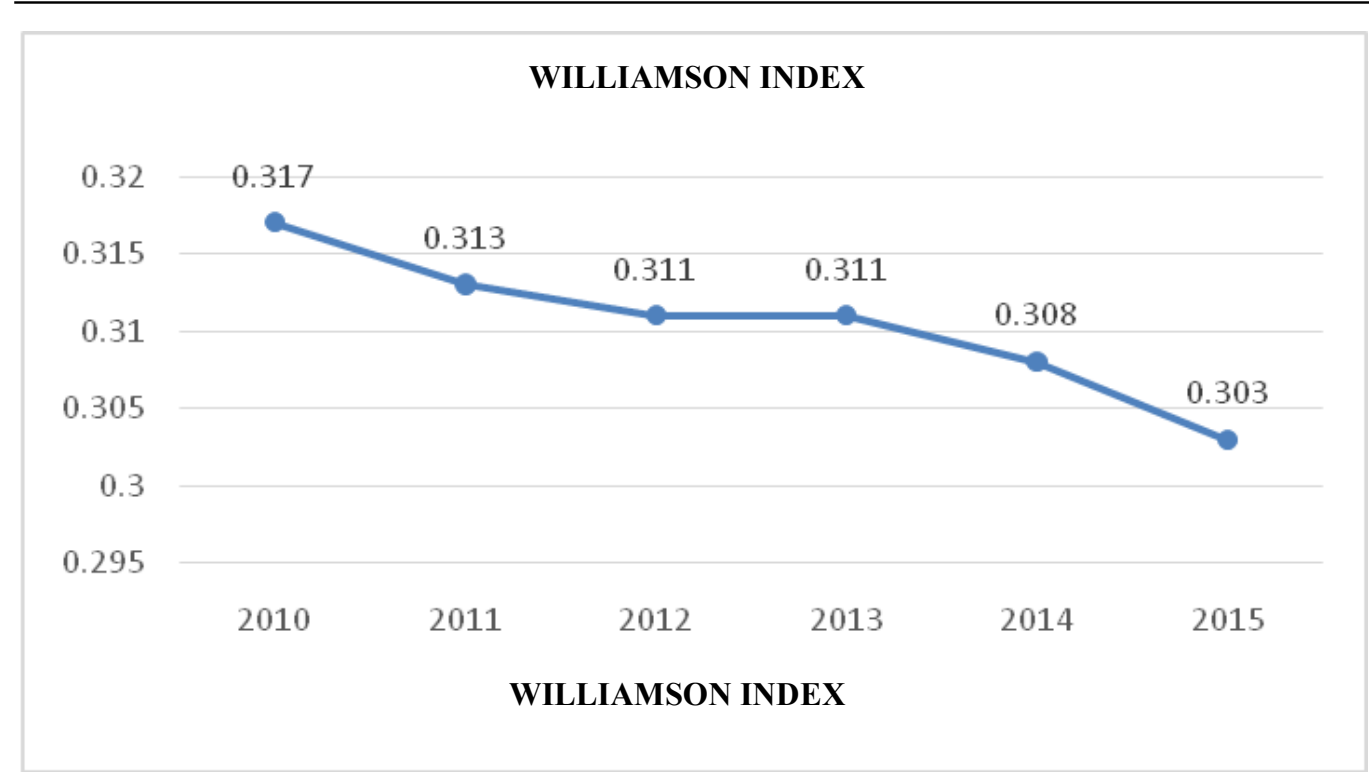

Figure 2.

Williamson Index Disparity without the Mining and Excavation Sector Source: data processed from table 6

The comparison of high economic disparity for districts / cities in South Kalimantan Province with and without mining sector for 2010-2015 periods is shown in Figure 3.

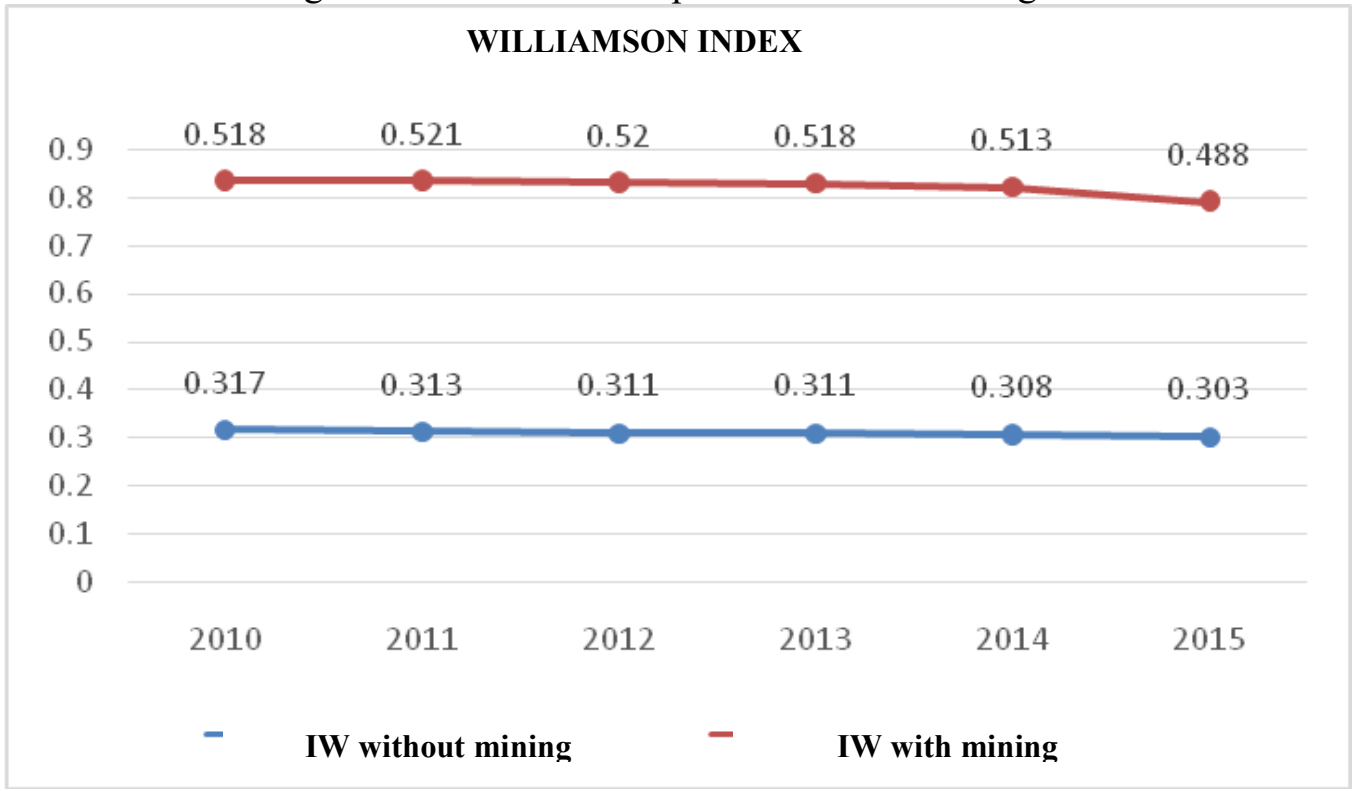

Figure 3.

Williamson Index of South Kalimantan Province Index

with and Without Mining for 2010-2015 period.

Source: data processed from tables 5 and 6

Figure 3 shows economic disparity with mining reached an average of 0.513 , higher than without mining at 0.310 . The disparity between regions is caused by differences in natural resource content to causes economic activity depend on primary sector, especially the mining (coal) sector and excavation and existence of natural resources, especially in mining sector 
with high productivity levels also increase the regional income per capita. Districts / cities index contributions to disparity development in South Kalimantan Province for 2010-2015 periods are shown in table 7.

\begin{tabular}{|l|l|l|l|l|l|l|c|}
\hline Districts & $\mathbf{2 0 1 0}$ & $\mathbf{2 0 1 1}$ & $\mathbf{2 0 1 2}$ & $\mathbf{2 0 1 3}$ & $\mathbf{2 0 1 4}$ & $\mathbf{2 0 1 5}$ & Average \\
\hline Tanah Laut & 0.001 & 0.001 & 0.000 & 0.001 & 0.003 & 0.006 & 0.002 \\
\hline Kotabaru & 0.191 & 0.188 & 0.190 & 0.190 & 0.189 & 0.185 & 0.189 \\
\hline Banjar & 0.135 & 0.134 & 0.132 & 0.134 & 0.133 & 0.132 & 0.133 \\
\hline Barito Kuala & 0.115 & 0.118 & 0.119 & 0.120 & 0.120 & 0.019 & 0.102 \\
\hline Tapin & 0.006 & 0.006 & 0.007 & 0.009 & 0.011 & 0.012 & 0.009 \\
\hline Hulu Sungai Selatan & 0.104 & 0.105 & 0.104 & 0.103 & 0.101 & 0.097 & 0.102 \\
\hline Hulu Sungai Tengah & 0.118 & 0.123 & 0.123 & 0.121 & 0.120 & 0.116 & 0.120 \\
\hline Hulu Sungai Utara & 0.140 & 0.140 & 0.139 & 0.139 & 0.137 & 0.135 & 0.138 \\
\hline Tabalong & 0.246 & 0.247 & 0.244 & 0.240 & 0.237 & 0.231 & 0.241 \\
\hline Tanah Bumbu & 0.185 & 0.179 & 0.171 & 0.157 & 0.147 & 0.140 & 0.163 \\
\hline Balangan & 0.234 & 0.241 & 0.244 & 0.255 & 0.260 & 0.256 & 0.248 \\
\hline Banjarmasin & 0.046 & 0.051 & 0.048 & 0.041 & 0.034 & 0.026 & 0.041 \\
\hline Banjarbaru & 0.062 & 0.066 & 0.067 & 0.067 & 0.067 & 0.065 & 0.066 \\
\hline South Kalimantan & $\mathbf{0 . 5 1 8}$ & $\mathbf{0 . 5 2 1}$ & $\mathbf{0 . 5 2 0}$ & $\mathbf{0 . 5 1 8}$ & $\mathbf{0 . 5 1 3}$ & $\mathbf{0 . 4 8 8}$ & $\mathbf{0 . 5 1 3}$ \\
\hline
\end{tabular}

Table 7.

Districts / cities Index Contributions to Disparity Development

Source: Calculation results

Table 7 shows the differences in Williamson Index contribution rates of each districts / cities. The Balangan District has highest average contribution compared to other districts / cities at 0.248. The second and third ranks are Tabalong and Kotabaru Districts, average of 0.241 and 0.189 , respectively. The three districts have a high contribution to disparity because the district has a large mining and excavation sectors to support economy of these districts. The smallest contributions to disparity are Tanah Laut and Tapin Districts with an average of 0.002 and 0.006 , respectively.

Tanah Laut and Tapin Districts have small index contribution even though these 2 districts have large mining and excavation sectors. It is different from Balangan, Tabalong and Kotabaru Districts which have a large mining and excavation sectors of GRDP in South Kalimantan Province. It makes Balangan District, Tabalong and Kotabaru Districts have high disparity index contribution rates. Previous analysis shows high disparity rates relates with large mining sector. Tanah Laut and Tapin Districts have a small contribution to disparity index because the GDP per capita of Tanah Laut and Tapin Districts is almost the same as the GRDP of South Kalimantan Province.

\section{Analysis the Pattern and Structure of Economic Growth}

The South Kalimantan Province consists of 13 districts / cities with different economic features highly depend on their resources, including: natural resources and human resources to drive economic activities, as well as regional infrastructure and policies to improve the economy. Economic growth and per capita GRDP of Districts / cities in South Kalimantan Province can be classified with Klassen Typology analysis. There are four classifications, namely: advanced and fast-growing districts / cities, advanced but depressed districts / cities, fast developing districts / cities, relatively lagging districts / cities. 
The districts / cities with advanced but depressed classification are Kotabaru, Tabalong, and Tanah Bumbu Districts. Kotabaru, Tabalong, and Tanah Bumbu Districts have lower average per capita income and economic growth than South Kalimantan Province. This districts / cities are an advanced district but recently have experienced relatively small growth due to depressed main activities.

Kotabaru District is dominated by secondary sector, with processing industry sector for more than $30 \%$ in $2010-2015$. The second place was primary sector, namely the mining and excavation sector for more than $21 \%$ in 2010-2015 and in third place is the agriculture, forestry and fisheries sector for more than 19\% in 2010-2015. Kotabaru District has abundant wealth such as coal, iron ore and palm oil. Kotabaru is the region with largest oil palm farmers in South Kalimantan. While the economic structure of Tabalong and Tanah Bumbu District is dominated by primary sector, namely mining and excavation, especially coal, but the trend has always declined from 2013-2015 due to sluggish demand from foreign countries for coal such as China, Japan and India. This decline has an impact on economic growth in these two districts. However the macro of GDP value per capita of Tabalong and Tanah Bumbu districts is still high.

The districts / cities with developing rapidly classification are Hulu Sungai Tengah, Hulu Sungai Utara, Banjarmasin City, and Banjarbaru City. Hulu Sungai Tengah District, North Hulu Sungai District, Banjarmasin City, and Banjarbaru City have lower per capita income and higher economic growth compared to average per capita income and economic growth of South Kalimantan Province. This indicates that District / Cities income is still relatively low even though Banjarmasin City has a lot of income but a large population cause low per capita income.

The agriculture, fisheries and forestry sectors give largest contribution to economy of Hulu Sungai Tengah district for more than 25\% and Hulu Sungai Utara in amount for more than $18 \%$. However, this sector continued to decline from 2011-2015. This was caused by reduced land, a non-conducive climate and flood land. This decline creates slow economic growth.

The Banjarmasin city is dominated by secondary and tertiary sectors, namely the manufacturing industry sector of $18-21 \%$. The second place is financial and insurance services by $11-13 \%$ and third place is grocery and retail trade, car and motorcycle repairs at 11-12\%. Banjarmasin City does not have a mining area and relies more on service sector. Banjarbaru City is same as Banjarmasin City that dominated by secondary sector and tertiary sector, but in first place Banjarbaru city is dominated by transportation and warehousing sector for $18-21 \%$, second place is construction for more than $14 \%$ and third place is administration government, defence and social security for $12-13 \%$. The rest is other sectors contribution.

The Tanah Laut, Banjar, Barito Kuala and Hulu Sungai Selatan districts that have per capita income and economic growth below the average of South Kalimantan Province. The four districts are relatively underdeveloped. The four districts contribute the most GRDP from primary sector. Even Banjar and Barito Kuala districts are largest producer rice in South Kalimantan. Both districts supply almost one third of rice production in South Kalimantan Province. Based on above description, table 8 shows a typology the classification of patterns and structure of economic growth in each District / cities in South Kalimantan Province (table: 8). 
Table 8.

Grouping the Regional Development Based on Klassen Typology

\begin{tabular}{|c|c|c|}
\hline Per capita income & $\begin{array}{c}\text { Yi }>\text { Y } \\
\text { Per capita income } \\
\text { Districts / cities }>\text { per } \\
\text { capita income of South } \\
\text { Kalimantan Province }\end{array}$ & $\begin{array}{l}\qquad \mathrm{Yi}<\mathrm{Y} \\
\text { Per capita income Districts / } \\
\text { cities }<\text { per capita income of } \\
\text { South Kalimantan Province }\end{array}$ \\
\hline \begin{tabular}{l}
\multicolumn{1}{c}{$\mathrm{r}$ i $>\mathrm{r}$} \\
Economic growth of \\
Districts / cities $>$ economic \\
growth of South \\
Kalimantan Province areas
\end{tabular} & $\begin{array}{l}\text { Fast and high-growth } \\
\text { regions: } \\
\text { Tapin dan Balangan }\end{array}$ & $\begin{array}{c}\text { Fast growth regions: } \\
\text { HSS,HSU,Banjarmasin, dan } \\
\text { Banjarbaru }\end{array}$ \\
\hline $\begin{array}{l}\text { Economic } \quad \mathrm{r} \mathrm{i}<\mathrm{r} \\
\text { growth of } \\
\text { Districts / cities }<\text { economic } \\
\text { growth of South Kalimantan } \\
\text { Province areas }\end{array}$ & $\begin{array}{l}\text { Advanced but depressed } \\
\text { regions: } \\
\text { Kotabaru, Tabalong,dan } \\
\text { Tanah Bumbu }\end{array}$ & $\begin{array}{c}\text { Underdeveloped regions: } \\
\text { Tanah laut, Banjar, Barito } \\
\text { Kuala, HST }\end{array}$ \\
\hline
\end{tabular}

\section{CONCLUSIONS}

1. Williamson Index shows that disparity among districts / cities in South Kalimantan Province tends to decrease and has a fairly high average of 0.513 (included mining and excavation sectors). Excluding the mining and excavation sectors will decrease the disparity at 0.310 . This is due to differences in natural resource content to causes economic activity very depend on primary sector, especially the mining and excavation sectors. The biggest contribution to disparity is in Balangan District at average of 0.248, second is third, Tabalong District at average 0.241 and third is Kotabaru District at 0.189. The smallest contribution to disparity level is Tanah Laut District at an average of 0.002 .

2. Klassen typology for economic growth and per capita income in 2010-2015 observations for districts / cities in South Kalimantan Province create 4 groups, namely Fast and high-growth regions for Tapin and Balangan Districts, Advanced but depressed regions for Kotabaru, Tabalong and Tanah Bumbu Districts. Fast growth regions for Hulu Utara District, Sungai Hulu Selatan District, Banjarmasin City and Banjarbaru City, and Underdeveloped regions for Tanah Laut, Banjar, Barito Kuala and Hulu Sungai Tengah Districts.

\section{SUGGESTIONS}

1. For Advanced but depressed regions, the provincial government should improve the coordination of districts / cities in an effort to spread infrastructure development, implement effective regional government to make comprehensive development to minimize disparity to achieve equitable development to increase people's welfare and seeks to develop centers growth in other sectors to reduce concentration in mining sector because in long-term the mining will run out.

2. Fast-growth regions should maintain and improve the classification of their regions with efforts to enhance their potential. 
3. Advanced but depressed regions, development of district's potential such as sustainable natural resource management in developing oil palm and rubber can be improved and supported by technology to increase productivity and provide added value to goods produced to make manufacturing industry and other sectors can develop in order they are not depend on mining sector anymore because the sector will eventually run out.

4. Underdeveloped regions should develop planning policies aimed to develop sustainable natural resources potential as agriculture, plantations, livestock and fisheries because these districts have large agricultural, plantation, livestock and fisheries sectors, quality improvement of human resources, technology, creativity, and entrepreneurship development and prioritize districts that are lagging behind while concern to developed, developed but depressed districts and cities that are rapidly developing.

\section{REFERENCES}

Arsyad, Lincolin. (1999). Ekonomi Pembangunan, Edisi 3. Yogyakarta: Stie Ykpn Bpfe.

Arsyad, Lincolin. (1999). Pengantar Perencanaan dan Pembangunan Ekonomi Daerah. Yogyakarta: BpfeYogyakarta.

Badan Pusat Statistik. (2011). Kalimantan Selatan dalam Angka 2011.Banjarmasin: Badan Pusat Statistik Kalimantan Selatan.

Badan Pusat Statistik. (2012). Kalimantan Selatan dalam Angka 2012.Banjarmasin: Badan Pusat Statistik Kalimantan Selatan.

Badan Pusat Statistik. (2013). Kalimantan Selatan dalam Angka 2013.Banjarmasin: Badan Pusat Statistik Kalimantan Selatan.

Badan Pusat Statistik. (2014). Kalimantan Selatan dalam Angka 2014.Banjarmasin: Badan Pusat Statistik Kalimantan Selatan.

Badan Pusat Statistik. (2015). Kalimantan Selatan dalam Angka 2015.Banjarmasin: Badan Pusat Statistik Kalimantan Selatan.

Badan Pusat Statistik. (2016). Kalimantan Selatan dalam Angka 2016.Banjarmasin: Badan Pusat Statistik Kalimantan Selatan.

Badan Pusat Statistik. (2015). Produk Domestik Regional Bruto Kabupaten/Kota Di Provinsi Di Kalimantan Selatan Menurut Lapangan Usaha Tahun 2010-2014.: Banjarmasin: Badan Pusat Statistik Kalimantan Selatan.

Badan Pusat Statistik. (2016). Produk Domestik Regional Bruto Kabupaten/Kota Di Provinsi Di Kalimantan Selatan Menurut Lapangan Usaha Tahun 2011-2015. Banjarmasin: Badan Pusat Statistik Kalimantan Selatan. Boediono.(1985). Teori Pertumbuhan Ekonomi. Yogyakarta: Bpfe-Ugm.

Devi Yanti Rahayu Sitorus. (2012). Analisis Pertumbuhan Ekonomi dan Ketimpangan Pendapatan Antar Kecamatan di Provinsi Kalimantan Timur Tahun 2001-2009 [Skripsi]. Semarang. Universitas Diponegoro. Fiqri Riza Jauhari. (2010). Analisis Pertumbuhan Ekonomi dan Ketimpangan Pendapatan Antar Kecamatan di Kabupaten Banjar di Provinsi Kalimantan Selatan Tahun 2000-2008 [Tesis]. Banjarmasin. Universitas Lambung Mangkurat.

Jhingan M.L. (2012). Ekonomi Pembangunan Dan Perencanaan. Jakarta: Pt.Raja Grafindo Persada. Mudrajad, Kuncoro. (2010). Masalah, Kebijakan, Dan Politik Ekonomika Pembangunan. Jakarta: Erlangga. Sadono, Sukirno. (2006). Ekonomi Pembangunan Proses, Masalah dan Dasar Kebijakan.Jakarta: Kencana. Prenada Media Group.

Sjafrizal, (2012).Ekonomi Wilayah dan Perkotaan.Jakarta: Raja Grafindo Persada.

Sjafrizal.(2008). Ekonomi Regional Teori dan Aplikasi.Padang: Baduose Media.

Todaro, Michael P. Dan Smith,Stephen. (2006). Pembangunan Ekonomi Edisi Kesembilan. Munandar,Haris[ Penerjemah], Jakarta: Erlangga.

Yuki Angelia.(2010). Analisis Ketimpangan Pembangunan Wilayah di Provinsi DKI Jakarta Tahun 1995-2008 [skripsi]. Semarang. Universitas Diponegoro. 